made into the aerial oxidation of the hydrochloric acid which is produced as a by-product of organic chlorination processes. The academic chemist finds to his surprise that the obsolete Deacon and Weldon processes are likely to be resuscitated on economic grounds.

These two books are well illustrated with line diagrams and plates. The authors and publishers are to be congratulated on these books which keep up the high ster.dard set by the first volume in this series: Sulphuric Acid: Manufacture and Uses, published by the Kynoch Press for Imperial Chemical Industries, Ltd. in 1955 .

M. J. NEWLANDS

\section{ISOTOPES IN HEMATOLOGY}

The Use of Isotopes in Hrematology

By L. G. Lajtha. Pp. $\mathrm{x}+83$. (Oxford: Blackwell Scientific Publications; Springfield, IIl.: Charles C. Thomas, 1961.) 218. net.

THE application of isotopic techniques to hæmatological problems is standard procedure in modern medioine. All too often their use has assumed the significence of a status symbol. Estimation of blood and plasma volume, the mean life-span of the erythrocyte and the absorption of radioactive cobalamin are procedures of established value. There is therefore a place for an authoritative account covering these and related topics.

The first two chapters of Dr. Lajtha's book describe the estimation of plasma and red cell mass and the estimation of the mean cell life of the erythrocyte. The next two are concerned with radioactive vitamin $B_{12}$ and iron, and there are two short chapters on white cell and platelet tagging and autoradiography.

The section on autoradiography is undoubtedly the best and reflects the author's vast experience in this field. The technique of preparing autoradiographs is set out in precise detail and the description is warmly recommended to anyone proposing to work in this field. The other sections are loss happy. The description and comment may well meet the need of the general hæmatologist who looks for guidance in setting up and interpreting tests involving the use of isotopes, but is anlikely to please the expert in the various fields.

Surface counting techniques are mentioned in somewhat general terms, but a detailed account of how one should set about doing them and how to interpret the results is absent. The estimation of mean cell life using chromium-51 is always of interest in a hæmolytic anæmia, but occasionally informa. tion about the site of destruction of the red cells may provide decisive information as to whether splenectomy is indicated or not. Simultaneous iron-59 and chromium-51 studies, the former providing the additional information about the site of red cell formation, are often performed together and perhaps should have found a place in this book.

Equally important is the emphasis the author places (or fails to place) on various procedures. Both an in vitro and in vivo method for labelling red cells with chromium are described and little guidance is given $2 \mathrm{~s}$ to which is the method of choice.

Similarly, four methods of estimating absorption of vitamin $B_{12}$ labelled with cobalt-58 are listed and discussed, namely: the frecal excretion test, the urinary excretion test, the hepatic uptake test and the plasma test. The change in plasma radioactivity after an oral dose of vitamin $\mathbf{B}_{12}$ does not merit consideration as a routine test of absorption of vitamin $B_{12}$ even if material of sufficiently high specific activity were available. It certainly has no place as a screening procedure. On the other band, many would regard the hepatic uptake of vitamin $B_{12}$ labelled with cobalt-58 after an oral dose in a far more favourable light than does Dr. Lajtha. It is independent of the ability and willingness of the patient to collect his fæces ( $?$ for 15 days) or urine.

Finally, a section devoted to the behaviour of the limited range of isotopes of use in the hrematological laboratory and to the equipment that the hæmatologist could most profitably invest in in order to count these isotopes would have greatly enhanced the value of the book.

I. Chanarin

\section{ZOOLOGICAL LITERATURE FOR 1958}

The Zoological Record

Vol. 95 : Records of Zoological Literature relating chiefly to the year 1958. Edited by G. Burder Stratton, assisted by Marcia A. Edwards. Pp. $v+2234$. (London: Zoological Society of London, 1961.) 1608.

THE present volume of The Zoological Record, relating chielly to the literature of 1958 , is bigger than ever, and provides good evidence, if this were necessary, of the great expansion of the subject in recent years. The Record, apart from being a necessity to anyone engaged in taxonomic studies, also furnishes a good indiastion of the amount of work being carried out in the different groups of the animal kingdom. In addition, the valuable system of classifying publications according to subject enables one to see the relative attention being devoted to the various aspects in esch of the eighteen groups of animals listed. A study of the Insecta, by far the largest section, comprising $\mathbf{6 6 0}$ pages, shows an increasing number of publications dealing with physiology and ecology, and in the subject index the number of pages under each heading is as follows: insect morphology 9, development 12, physio'ogy 21 , bionomics 10, ocology 19 , ovolution 8 , geographical and faunistic 27. The main divisions show little difference from those in recent years: Mollusea, with 187 pages, is followed by Protozos 147, Pisces 141, Vermes 131, Mammalia 125, Arachnida 123, Aves 112, Crustacea 110, Amphibia 100, Reptilia 93, Trilobita 86 and in gradually diminishing size to Porifers 7 . The number of new geners and subgenera is nil in Protochordata, one in Amphibia, and reaches a maximum of 949 in the Insecta. It is noteworthy that the total number of new genera and subgenera has shown no diminution in recent years and as evidenoe of the amount of taxonomic work in progress does not support the pessimistio views of certain authorities concerning the dearth of taxonomists.

This is the last volume to be iseued in bound form. Starting with Volume 96 (literature for 1959) the separate sections will be sent to subscribers as soon as they are published; a title-page and binding case will be forwarded when the volume is complete. This will bring information of eurrent research to users of the Record more quickly. In addition, the format, beginning with Volume 96, will be changed to crown octavo, to give the larger type area necessary for recording the expanding volume of literature each year.
Edward Hindue 